
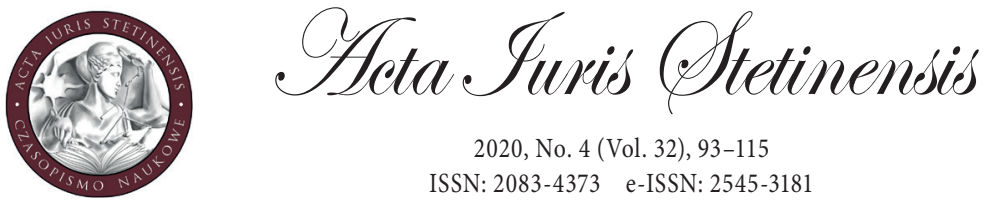

2020, No. 4 (Vol. 32), 93-115

ISSN: 2083-4373 e-ISSN: 2545-3181

DOI: $10.18276 /$ ais.2020.32-07

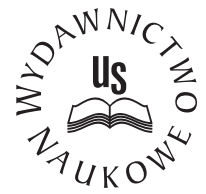

Marek Stawecki

Ph.D.

University of Szczecin, Poland

Faculty of Law and Administration

e-mail:marekstawecki@op.pl

ORCID ID: 0000-0003-3598-7787

\title{
Zoning fee as a public levy
}

\begin{abstract}
The zoning fee constitutes a public levy paid to the commune by the owners or perpetual usufructaries of properties. The purpose of the zoning fee is to compensate for the costs incurred by the local government units due to the adoption or change of the local spatial development plans.

The discussed fee may be collected pursuant to the provisions of local law if the market value of the property increased due to the implementation of a new or amended local spatial development plan.

It should be observed that the zoning fee is an element of settling accounts between the commune and entities, whose property value changed with the adoption of the new local spatial development plan or change of the previous plan.

The provisions do not clearly describe the legal nature of the zoning fee. Nonetheless, the public and legal status of the aforesaid fee was confirmed by judicial decisions.

Since the commune is not a taxpayer, the fee constitutes its own income. It is due to the fact that the zoning fee does not follow from the act and does not have an unpaid character. The obligation to pay the zoning fee is the result of a specific spatial policy of the commune.

Even though they were the subject of many judicial decisions, the provisions of the Act of 27 March 2003 on spatial planning and development referring to zoning fees still raise a lot of interpretation doubts as to their amount, date of payment or the very grounds for their existence. The objective of the article is to show the public and legal character of the aforesaid performance. The author is trying to prove that such a measure is by all means necessary, but
\end{abstract}


its structure requires certain amendments, which was possible by means of the test method in the form of an analysis of legal acts and selected judicial decisions.

Keywords: zoning fee, local spatial development plan, public levy, commune's own income, participation in the costs of spatial planning

\section{Introduction}

The zoning fee constitutes a public levy paid to the commune by the land owner. Its purpose is to compensate for the costs incurred by the local government units due to the adoption or change of local spatial development plans. ${ }^{1}$

The regulations included in the Act on Spatial Planning and Development (hereinafter Act) ${ }^{2}$ referring to the local spatial development plan constitute the legal basis for determining the amount of the zoning fee. The amount is defined in percentage and may not exceed $30 \%$ of the increased land value. The legislator only specified the upper value. The commune's decision-making body is responsible for specifying the appropriate percentage rate. ${ }^{3}$

The competent executive body of the local government unit may request that the owner pay the zoning fee within 5 years from the date of adoption of the local spatial development plan. As a result, a notary is obliged to provide the abovementioned body with a copy of each agreement, whose subject is the disposal of the property located within the area covered by the local spatial development plan, which entered into force within the last 5 years from the date of its execution. ${ }^{4}$

The spatial planning that establishes the right to use the lands is closely related to the issues of building law by creating the foundations for the investment process. ${ }^{5}$

By analysing the above-mentioned fee, it should be observed that it is an element of settling accounts between the commune and entities whose properties' value changed with the adoption of the new local spatial development plan or with the change of a previous plan. On one hand, the owner or perpetual usufructary, who incurred losses due to the adoption or change of the plan, may demand

1 Strzelczyk, R., Podatki i opłaty dotyczace nieruchomości, Warszawa 2016, p. 227.

2 Act of 27 March 2003 on spatial planning and development, consolidated text: Dz.U. (Journal of Laws) of 2020, item 293.

3 Niewiadomski, Z., Planowanie i zagospodarowanie przestrzenne. Komentarz, 8th edition, Warszawa 2015, p. 300.

4 Gdesz, M. and Trembecka, A., Regulowanie stanu prawnego nieruchomości pod drogi, Katowice 2011, p. 201.

5 Budner, W., Gospodarka przestrzenna miast i aglomeracji, 1st edition, Poznań, 2019, p. 30. 
compensation from the commune, but on the other, if the land value increased, the commune will impose the fee on such owner or perpetual usufructary. ${ }^{6}$

The expression 'due to the adoption or change of the local spatial development plan' determines the time conjunction of the occurrence of the situation when the increase of the property's value is correlated with the obligation to make a one-off payment for the disposal of the property within 5 years from the date of the adoption of the plan, i.e. the increase of the property's value due to the adoption of the plan, determination of the purpose (more favourable than the present purpose) of the land, which is then sold by the owner, who derives financial benefits therefrom. ${ }^{7}$

Even though they were the subject of many judicial decisions, the provisions of the Act referring to zoning fees still raise a lot of interpretation doubts as to their amount, date of payment or the very grounds for their existence. The author is trying to prove that such a measure is by all means necessary in the spatial planning system, but its structure requires certain amendments. The author analysed and evaluated it in the administrative and legal area and in terms of financial and constitutional law. Another objective of the article is to show the public and legal character of the aforesaid performance.

The test method used in the article consists in the analysis of legal acts, views of legal scholars and commentators and judicial decisions.

\section{Character of the zoning fee}

The zoning fee is described in Article $36 \mathrm{sec} .4$ of the Act. It is a single public levy reflecting the participation of communes in the income from the disposal of immovable property, whose value increased due to the change of the local spatial development plan. ${ }^{8}$

To determine the property market value, many elements need to be compiled. ${ }^{9}$ One such element is the area. In most cases, the lands with identical area significantly differ in terms of their prices. It is due to the fact that many other issues have impact on the price amount of the property, such as, among other things, the

6 Plucińska-Filipowicz, A. and Wierzbowski, M., Ustawa o planowaniu i zagospodarowaniu przestrzennym. Komentarz, Warszawa 2018, p. 447.

7 Judgement of the Voivodeship Administrative Court in Kraków of 25 April 2019, II SA/Kr 205/19, LEX No. 2664924.

8 Nowak, M.J. and Tokarzewska-Żarna, Z., Gospodarka nieruchomościami. Kluczowe problemy prawne, Warszawa 2017, p. 85.

9 Bieniek, G. et al., Ustawa o gospodarce nieruchomościami. Komentarz, Warszawa 2012, pp. 473-474. 
location, legal status, neighbourhood, and technical infrastructure. ${ }^{10}$ One feature of the above-mentioned values is the fact that it usually changes. The level of prices of lands and changes related to the property in question, often beyond the control of its owner, are some of the many of the factors that influence the aforementioned value. ${ }^{11}$ According to the legislator, it was justified to introduce the regulation, as a result of which the communes had a share in profits of entities who are the property owners, which are built in connection with the activities of appropriate local government units. The above was reflected in a possibility of allowing the communes to collect the so-called zoning fee. The fees are commonly referred to as "renta" (Eng. literally: annuity). Obviously, the term is used almost simultaneously with the word 'fee. However, it is incorrect, as it creates unnecessary doubts - -it is not a renta, but a zoning fee. There is also no adjacent annuity, but an adjacent fee. Therefore, it would be necessary to call for appropriate definition of the subject public levy. The fees may be determined on the basis of the provisions included in local law if the land market value increased due to the adoption of the new local spatial development plan or change of the previous plan. ${ }^{12}$

The analysed fee constitutes a public-law liability. Such status has been confirmed by the court decisions. However, the regulations of the Tax Ordinance should not be applied to the aforementioned fee. ${ }^{13}$ The fee is the commune's own income, but may not be treated as tax. ${ }^{14}$ It does not result from the tax regulations and does not have unpaid character (as a matter of principle, it is the result of the adoption of the new local spatial development plan, which caused the increase of the land value).$^{15}$ When determining the amount of the aforesaid fee, the commune authorities perform tasks of public authorities. ${ }^{16}$ The obligation to define the analysed fee depends on two premises. First of all, it is necessary to ascertain the increase of

10 Jaworski, J. et al., Ustawa o gospodarce nieruchomościami. Komentarz, 5th edition, Warszawa 2017, p. 1030.

11 Źróbek, S. et al., Gospodarka nieruchomościami. Komentarz do wybranych procedur, Katowice 2011, p. 232.

12 Mielcarek, P. et al., Akta administracyjne dla aplikantów, Warszawa 2016, p. 59.

13 Act of 29 August 1997 - Tax Ordinance, consolidated text: Dz.U. (Journal of Laws) of 1997, No. 137 , item 926 , as amended.

14 Judgement of the Supreme Administrative Court of 7 November 2001, II SA/Gd 1948/01, "Orzecznictwo Sądów Polskich" 2003, Issue 2, item 16.

15 Judgement of the Supreme Administrative Court of 15 November 2006, II OSK 1370/05, LEX No. 321533.

16 Judgement of the Voivodeship Administrative Court in Warszawa of 28 June 2006, IV SA/Wa 2465/05, LEX No. 232967. 
the land value due to the adoption of the local spatial development plan. ${ }^{17}$ Furthermore, the owner must dispose the aforesaid properties, which will initiate the fee collection process and constitute the second premise for applying the analysed measure. ${ }^{18}$ Only if it is established that the new local spatial development plan has been adopted or a previous plan has been changed, the obligation to determine the zoning fee arises. Therefore, in the context of the above, it will be impossible to determine the above-mentioned fee if the land value increased solely due to the decision on land development and management conditions or decision on the site location of a public-purpose investment project. Furthermore, attention should be paid to the issue of disposing the property after the local spatial development plan has been amended due to the division of the larger property existing prior to such amendment. It should be stated that the commune is entitled to charge the zoning fee also if the physically separated part of the property or fractional part is disposed, despite the fact that Article $36 \mathrm{sec} .4$ of the Act does not explicitly provide for such cases. The Supreme Administrative Court adopted such view in its judgement of 14 February 2014, in which it explained that due to the connection between the zoning fee measure and the civil law transactions, it should be assumed - -to produce the effect as stipulated in Article $36 \mathrm{sec} .4$ and Article $37 \mathrm{sec} .7$ of the Act that the aforementioned provisions refer to such property that may be the autonomous subject of civil and law transactions. With the above in mind, it may be also a part of the property, but only after its geodetic or legal division. Therefore, the provision in Article $36 \mathrm{sec} .4$ of the Act applies also when the separated part of the property or its perfect fractional part (share) is disposed. ${ }^{19}$ The Supreme Administrative Court previously presented almost the same position in its judgement of 15 April 2008, in which it explained that pursuant to Article $36 \mathrm{sec}$. 4 of the Act of 27 March 2003 on Spatial Planning and Development, the property is also a part of land owned by the same owner, covered by the local spatial development plan, intended for a particular purpose defined therein, which - -after its geodetic or legal division- - may be an independent subject of civil and legal transactions. The above shows that the collection of the zoning fee is also possible in the event when the owner (perpetual usufructary) disposes of only a part and not the whole of a property, provided that

17 Nowak, M.J., Planowanie i zagospodarowanie przestrzenne. Komentarz do ustawy i przepisów powiq̨zanych, Warszawa 2019, p.192.

18 Judgement of the Supreme Administrative Court of 20 July 2006, II OSK 955/05, LEX No. 275481.

19 Judgement of the Supreme Administrative Court of 14 February 2014, II OSK 2216/12, LEX No. 1450902. 
other conditions stipulated in Article $36 \mathrm{sec} .4$ of the Act of 27 March 2003 on Spatial Planning and Development are satisfied. ${ }^{20}$

In conclusion, the discussed fee may be collected not only in the case of the sale of the whole property, but also a part thereof. Such a position was adopted by the Supreme Administrative Court in its resolution of 17 May 1999, in which it explained that a one-off payment mentioned in Article $36 \mathrm{sec}$. 4 of the Act of 27 March 2003 on Spatial Planning and Development may be also collected in the case of disposal of a part of the property if the value of the disposed property increased due to the amendment to the local spatial development plan. ${ }^{21}$ If the party sold only some plots divided after the adoption of the plan; then, to calculate the zoning fee, the increase rate of the plot value must be adopted, however in the form in which it existed on the day when the local spatial development plan was passed. ${ }^{22}$ Another condition imposing the obligation to determine the zoning fee is the disposal of the land. The term 'disposal' refers to such legal actions as sale, in-kind contribution, replacement and other forms of free disposal. Expropriation does not apply to the above actions. ${ }^{23}$ As the Supreme Administrative Court showed in its judgement of 14 January 2009, the decision on the zoning fee must be always issued in the case of the increase of the value of the land, even if it is insignificant, but has an impact on the attractiveness and price of the land. ${ }^{24}$ The zoning fee should reflect the difference between the value of the land before the plan was adopted and its value on the day of disposal. The analysed fee should be in line with the objective change in the value of the land and not with the price set by parties to a specific agreement. ${ }^{25}$ The provision in Article $36 \mathrm{sec} .4$ of the Act only refers to the increase of the value of the land', which is independent of the sales price. ${ }^{26}$ The increase of the value should be a straightforward result of the adoption of the local spatial development plan. The adoption or change of the local spatial development plan does not necessarily lead

20 Judgement of the Supreme Administrative Court of 15 April 2008, II OSK 408/07, LEX No. 467118.

21 Resolution of the Supreme Administrative Court of 17 May 1999, OPK 17/98, "Orzecznictwo Naczelnego Sądu Administracyjnego i Wojewódzkich Sądów Administracyjnych” 1999, No. 4, item 121,

22 Judgement of the Supreme Administrative Court of 19 November 2008, II OSK 1316/07, LEX No. 549384.

23 Brzezicki, T. et al., Opłaty i wybrane roszczenia dotyczace nieruchomości, Warszawa 2018, p. 26.

24 Judgement of the Supreme Administrative Court of 14 January 2009, II OSK 1810/07, LEX No. 509156.

25 Judgement of the Supreme Administrative Court of 15 December 2008, II OSK 1600/07, Legalis No. 164590.

26 Judgement of the Voivodeship Administrative Court in Gliwice of 6 September 2019, II SA/Gl 308/19, LEX No. 2723683. 
to the increase of the value of the land. The more so when the aforesaid changes are questionable in comparison with the previous plan. ${ }^{27}$ The actual way of using the property, which constitutes the point of reference for establishing the increase of the value of the property, refers to the actual condition of a given property at the time of implementation of the local spatial development plan, which, however, does not refer to potential or legally informal possibilities of the property development that may be convergent with the purpose stipulated in the plan. ${ }^{28}$ In the discussed case, situations when the value is increased, due not to the plan amendment, but, for instance, to expenditures incurred by the owner on his/her land, should also be taken into account. The above-described situation does not provide grounds for charging the zoning fee, as it should not be based on the increase of the value resulting from circumstances other than the adoption or change of the plan. ${ }^{29}$ The increase of the value of the property must be directly connected with the adoption or change of the plan. Nevertheless, to determine whether the increase of the value of the property has actually occurred, it is necessary to compare the 'present' value with the 'previous' value. ${ }^{30}$ Furthermore, there will be no grounds to impose the fee on the land disposers if, after the amendment to the local spatial development plan, the properties have become more attractive but the purpose of the aforesaid land has not changed. Therefore, when establishing the zoning fee, it is important to show not only the actual increase of the value, but also the direct cause and effect relationship between the above-mentioned change in the value and arrangements made in the new local spatial development plan. ${ }^{31}$

To determine the fee in question, the provisions of the Act of 29 July 1997 - Tax Ordinance are not applicable. The zoning fee is a special type of the commune's income, which is included in the commune's income along with, among other things, taxes and other fees mentioned in Article $54 \mathrm{sec} .2$ point 6 Act of 8 March 1990 on Local Self-Government. ${ }^{32}$ Despite the fact that it has some characteristics of a tax in light of Article 6 of the Act of 29 August 1997 - Tax Ordinance, i.e. it

27 Judgement of the Supreme Administrative Court of 19 March 2009, II OSK 254/08, LEX No. 525774 .

28 Judgement of the Voivodeship Administrative Court in Gdańsk of 17 April 2019, II SA/Gd 811/18, LEX No. 2653240.

29 Judgement of the Supreme Administrative Court of 4 July 2008, II OSK 774/07, “Wspólnota” 2008, No. 41 , item 34 .

30 Judgement of the Voivodeship Administrative Court in Kraków of 26 November 2019, II SA/Kr 903/19, LEX No. 2761195.

31 Judgement of the Supreme Administrative Court of 13 July 2009, II OSK 1108/08, LEX No. 552816.

32 Act of 8 March 1990 on local self-government, consolidated text: Dz.U. (Journal of Laws) of 2020, item 713. 
is a public-law gratuitous performance, which is obligatory and non-refundable to the local government unit, but also at variance with the requirements of the invoked regulation not resulting from the Tax Ordinance. The Planning and Development Act may not be considered the Tax Ordinance. It does not follow from the provisions of the Planning and Development Act that the legislator's intent was to treat the discussed fee as tax and there are no grounds for presuming it and apply the provisions of the Tax Ordinance to such fee. ${ }^{33}$ The fees result from a specific spatial policy of the commune, which is based on rational spatial management. Despite certain characteristics that make the fee similar to the tax, there are significant differences. If the legislator wanted to treat the zoning fee as ta tax or another non-tax receivable subject to the provisions of the Tax Ordinance, the legislator would make it in an explicit manner or would at least oblige other entities to apply the Tax Ordinance in such matters. Since the legislator did not do it, such activity should not be alleged. Tax obligations must be explicit, not implied. This is the basis for the democratic state under the rule of law (Article 2 of the Constitution of the Republic of Poland). ${ }^{34}$

In summary, it must be stated that not all receivables from the budget of the lowest local government unit, even with dominant characteristics of the tax, constitute the budgetary receivables with respect to which the regulations of the Tax Ordinance apply. It is the Act that determines whether the provisions of the Tax Ordinance will apply or not; thus, the above should not be implied in any manner. If it is necessary to imply, then the implication should be reverse, namely, it should be stated that the provisions of the Administrative Code are applicable to such matters $^{35}$, since these provisions and not the provisions of the Tax Ordinance have the character of the norms widely applied in administrative proceedings (Article 1(n) of the Code of Administrative Procedure).$^{36}$ Therefore, the position, in accordance with which it is necessary to apply the provisions of the Code of Administrative Procedure during the procedure governing the establishment of the zoning fee amount, seems well-founded. Such position prevails in the judicial decisions of the Supreme Administrative Court. ${ }^{37}$ Since none of the provisions of the Act oblige

33 Borodo, A., Finanse publiczne RP. Zagadnienia prawne, Bydgoszcz 2000, p. 37.

34 Constitution of the Republic of Poland of 2 April 1997, consolidated text: Dz.U. (Journal of Laws) of 1997, No. 78, item 483, as amended.

35 Act of 14 June 1960 Code of Administrative Procedure, consolidated text: Dz.U. (Journal of Laws) of 2020 , item 256 .

36 Judgement of the Supreme Administrative Court of 16 September 2008, II OSK 1030/07.

37 See Judgement of the Supreme Administrative Court of 6 April 2006, II OSK 710/05, not published; Judgement of the Supreme Administrative Court of 22 June 2007, II OSK 935/06, not 
the authorities establishing the amount of the zoning fee to use the tax procedure, it should assumed that, pursuant to Article 1 of the Code of Administrative Procedure, the provisions of such Code should be applicable to the aforesaid matters. In other words, the issue of the zoning fee as a public levy not regulated in the Tax Ordinance should not be excluded from the objective scope of the Code of Administrative Procedure, by virtue of Article $3 \$ 1$ point 2 of the Code..$^{38}$

Article 217 of Constitution of the Republic of Poland stipulates that the levying of taxes and other public levies shall be by means of statute. This is the case of the zoning fees, since they were regulated in the statutory legal acts due to the fact that they are public-law liabilities.

\section{Local law versus zoning fee}

By virtue of Article 36 sec. 4 of the Act, the zoning fees should be defined in the local spatial development plan. Furthermore, pursuant to Article $15 \mathrm{sec} .2$ point 12 of the above legal act, it should be stated that the aforesaid plans must include the interest rates that constitute grounds for their establishment. ${ }^{39}$ The interest rate may not be higher than $30 \%$ of the increased property value. The commune's decisionmaking body may freely determine the interest rate for the subject fee within the above-mentioned limits. However, the fee rate may not be established at the level of $0 \%$. Article $15 \mathrm{sec} .2$ point 12 of the analysed Act clearly stipulates that the local spatial development plan should define the interest rates, on the basis of which the fee as provided for in Article $36 \mathrm{sec} .4$ of the Act was determined. With the above in mind, it should be concluded that the obligation to define the interest rates in a manner allowing to establish the zoning fee exists, which makes it impossible to define the zero interest rate. ${ }^{40}$

It should be emphasised that the zero rate not only does not fall within the legal framework as stipulated in Article $36 \mathrm{sec} .4$ of the Act, but also potentially nullifies the will of the employer that indicates the zoning fee as one of the elements of the

published; Judgement of the Supreme Administrative Court of 15 April 2008, OSK 408/07, not published; Judgement of the Supreme Administrative Court of 2 April 2008, II OZ 287/08, not published.

Judgement of the Supreme Administrative Court of 7 February 2006, I OSK 421/05, not published.

39 Rokicka-Maruszewska, K., Administracyjnoprawne aspekty opłaty planistycznej, Warszawa 2019, p. 46.

40 Judgement of the Voivodeship Administrative Court in Białystok of 30 March 2006, II SA/Bk 100/06, LEX No. 194598. 
public levy system, including the commune's budgetary income. ${ }^{41}$ What is more, it is allowed not to establish the analysed fee rates for some areas covered by the new or amended plan. It is justified only when, during the work on the provisions of the new plan, it is shown that the value of specific lands will not change due to the plan implementation--hence, the land value will remain at the same level. If there are no grounds for expecting any increase in the property value, since - -due to the adoption of the plan, the purpose of the land does not change (present purpose will not be more beneficial than the new purpose or will equal thereto)- - the existence of the interest rate of the zoning fee will be unjustified. In light of the above, it is evident that the obligation to determine the interest rates is not unconditional with respect to all areas covered by the draft plan. ${ }^{42}$ This will be the case when the present purpose of the property, resulting from the provisions of the previous local spatial development plan or actual purpose of such property - -the manner of its current use, if it was not subject to the provisions of the local plan- - proves equal to the purpose defined in the newly adopted local spatial development plan. ${ }^{43}$

When analysing the discussed topics, attention should be paid to the issue of invalidity of the local spatial development plans. A situation may occur when the regulations of the above Act have the defect of invalidity. When invalidity of the above-mentioned Act is ascertained (in whole or in part), the zoning fee will be reimbursed to the current owner or perpetual usufructary. The zoning fee will not be provided with the entity that incurred it, but with the entity that is currently in the possession of a given land. ${ }^{44}$ The regulations included in the acts concerning the local spatial development plans alone are essential to determine the zoning fee. It should be noted that it is impossible to establish such fee when the interest rate was not articulated in the above-mentioned legal act. In such case, the issuance of the decision would lead to the opinion that the decision was delivered without any legal basis and has the defect of invalidity. ${ }^{45}$ In light of the above, it should be stated that if there is no plan, neither the commune's decision making body - -by way of a dif-

41 Decision of the Voivode of Podlasie of 1 March 2006, PN.II.A.Ch.0911 - 41/06, "Wspólnota" 2006, No. 13 , item 46.

42 Judgement of the Voivodeship Administrative Court in Gliwice of 22 November 2007, II SA/Gl 377/07, LEX No. 340415.

43 Judgement of the Supreme Administrative Court of 10 June 2020, II OSK 3818/19, LEX No. 3026019.

44 Niewiadomski, Z., Planowanie i zagospodarowanie przestrzenne. Komentarz, 5th edition, Warszawa 2009, p. 288.

45 Judgement of the Supreme Administrative Court of 15 December 2008, II OSK 1600/07, Legalis No. 164590. 
ferent resolution- - nor the commune head, the mayor, or the president - -by way of the decision on the development conditions- - may determine the amount of the interest rates on the increased land value. ${ }^{46}$ Currently, there are no regulations providing the commune's decision making-body with the grounds for determining the interest rate of the zoning fee in the absence of the development plan.

The issues of the analysed institution were also the subject of the reflections of the Constitutional Tribunal. In its judgement of 9 February 2010, the Constitutional Tribunal analysed the following circumstances: the local spatial development plan was revoked, then, after several years, when the aforementioned Act did not exist, the new local spatial development plan was passed, specifying the identical purpose of the land as with the previous plan. ${ }^{47}$ The real problem was the comparison of the land values. ${ }^{48}$ The principle is that it is necessary to compare the present and previous value of the land. However, it should be noted that the legislator failed to specify which values such comparison should concern. The establishment of the current value should not be problematic, as it is defined while considering the purpose included in the valid plan. Nonetheless, the situation may be different when determining the 'previous' value. In such case, the ineffective plan should not be invoked, as the purpose of the land stipulated in the 'old' plan is insignificant. The fact is, that the value has increased and, hence, the obligation to impose and pay the fee occurred is related to the criterion of the actual land use. It is irrelevant whether the subject value is or is not in line with the purpose defined in the plan that expired.

The condition of the increase in the value must be objective and verifiable externally (see Article $36 \mathrm{sec} .4$ in connection with Article $37 \mathrm{sec} .1$ of the Act), thus, it requires detailed elaboration in the valuation survey. Pursuant to Article $37 \mathrm{sec} .1$, sentence 2 of the Act, the value is calculated as the difference between the value established for the land purpose according to the local spatial development plan after its amendment and the value determined for the land purpose according to the local spatial development plan before its amendment. By the will of the legislator, the certified property valuer and competent body are obliged to consider only the planning purpose, leaving aside the actual manner of using the disposed property. Such a solution may actually lead to a situation where the property value, according to its status before the plan amendment, is established in accordance

46 Judgement of the Voivodeship Administrative Court in Białystok of 14 January 2010, II SA/Bk 603/09, LEX No. 554968.

47 Judgement of the Constitutional Tribunal of 9 February 2010, P 58/08, Dz.U. (Journal of Laws) of 2010, No. 24, item 124.

Bieniek, G. et al., Ustawa o gospodarce nieruchomościami. Komentarz, Warszawa 2005, pp. 838-842. 
with a planning purpose that does not correspond to the actual manner of using the property. However, it is a statutory manifestation of the general aim of the legislator to maintain compliance between the planning purpose and the actual purpose of the property. ${ }^{49}$ The necessity to develop local spatial development plans is not a new task for communes. The land owners may not bear negative consequences of the plan's ineffectiveness due to the omissions of the local government. The fact that the value increased should be analysed as a consequence of the adoption of the new plan immediately following the previous one, not as the result of the discontinuance of planning or temporary lack of any local spatial development plan, including all effects in the form of the obligation to pay the fees.

In conclusion, the Constitutional Tribunal stated that Article $37 \mathrm{sec} .1$ is unconstitutional in the part when the increase of the property refers to the criterion of the actual use of the property in the event when the land purpose was described identically as in the plan, which - -by operation of law- - became ineffective on 31 December 2003.

\section{Method of establishment of the zoning fee}

The commune head, mayor, or president of the city may introduce a one-off zoning fee, mentioned in Article $36 \mathrm{sec} .4$ of the Act when the following cumulative conditions are met:

1) the commune council passed or amended the local spatial development plan, while establishing the interest rate of the zoning fee;

2) due to the adoption or change of the local spatial development plan, the property value increased;

3) the property covered by the planning act was acquired by the owner or perpetual usufructary after the resolution on the local spatial development plan or amendments thereto became effective, yet no later than 5 years after the entry into force of this resolution;

4) the administrative proceedings concerning the zoning fee were initiated before 5 years following the effective date of the resolution on the local spatial development plan or amendments thereto. ${ }^{50}$

49 Judgement of the Supreme Administrative Court of 7 November 2019, II OSK 3166/17, LEX No. 2761923.

50 Judgement of the Voivodeship Administrative Court in Olsztyn of 10 March 2020, II SA/Ol 965/19, LEX No. 2906089. 
The increase of the property value is usually correlated with the entry into force of the new plan, which changes the possibilities of land development from less attractive to more attractive in economic terms, but also as regards the arrangements that do not change the function of the land, but which change the parameters of its structures in a more economically beneficial manner. In the case of the increase of the property value, the expenditures incurred by the owner or other entity (e.g. the commune, State Treasury) related to the construction of technical infrastructure are not taken into consideration. ${ }^{51}$ The analysed public levy constitutes the product of the following elements - the interest rate and the basis for determining the fee. It is established based on the increase in value which results from the difference between the value defined while taking into account the land purpose effective after the adoption or change of the local spatial plan, and the value determined while considering the land purpose effective before the change of such plan or the actual manner of using the land before the adoption of the plan..$^{52}$ If the changed purpose of the land refers to a part thereof, the fee amount is calculated solely for this part of the property, which is affected by the change resulting from the provisions of the plan. By including the value of the property, whose purpose remained unchanged after the adoption of the plan, the owner will be wrongly obliged to make undue payments, not resulting from Article $36 \mathrm{sec} .4$ of the Act. ${ }^{53}$

The property value must increase on the day of the adoption of the local spatial development plan or amendment thereto. If this is not the case, i.e. despite the implementation of the local spatial development plan the property value has not increased, the administrative authority (commune head, mayor, president of the city) has no grounds for determining the fee referred to in Article $36 \mathrm{sec} .4$ of the Act and to demand payment thereof. This would be the case when the current purpose of the property resulting from the provisions of the local spatial development in force by the time of the implementation of the new plan or change of the previous plan remains equivalent to the purpose stipulated in the new local spatial development plan..$^{54}$ As already mentioned, the sales prices adopted by the parties are insignificant when calculating the fee amount. To avoid prices significantly different than the average market prices, various valuation methods and techniques

51 Judgement of the Voivodeship Administrative Court in Kraków of 12 November 2019, II SA/Kr 739/19, LEX No. 2749850.

52 Leoński, Z. et al., Prawo zagospodarowania przestrzeni, Warszawa 2019, pp. 355-356

53 Judgement of the Voivodeship Administrative Court in Łódź of 25 July 2019, II SA/Łd 152/19, LEX No. 2707135.

54 Judgement of the Voivodeship Administrative Court in Kraków of 5 April 2019, II SA/Kr 27/19, LEX No. 2656072. 
are applied to determine the property value while using the prices of property with similar characteristics and purposes for the sake of comparison. The analysed fee is connected with the objective increase of the property value, whereas the price amount determined by the parties to a given legal action in the sales contract has nothing to do with the obligation to pay such fee. ${ }^{55}$ With the above in mind, it should be stated that the profit derived from the sales by the entity is absolutely irrelevant. The fundamental issue is the actual increase of the land value due to the amendments to the provisions of the plan. ${ }^{56}$ The commune is responsible for proving that the value of the property has actually increased. The above is confirmed on the basis of a valuation survey prepared by a property valuer. ${ }^{57}$ This opinion constitutes sufficient evidence in the proceedings to determine the zoning fee. ${ }^{58}$ The fact that the valuation survey was carried out by a property valuer, hence the person meeting certain professional criteria, is not sufficient to be considered as having probative value. Public administration bodies are obliged to specifically explain the case and undertake the necessary actions to appropriately establish the property value, thus to evaluate the credibility of the opinion drafted during the proceedings, since these are the public administration bodies, not the property valuer, who hold executive powers to form the administrative and legal relationship outlining the rights and duties of the parties. ${ }^{59}$

On 28 November 2003, the analysed Act was amended ${ }^{60}$ which resulted in the replacement of the term 'sale' with the word 'disposal' in Article 36 of the Act. The purpose of the above change was to expand the scope of legal events whose existence contributes to the possibility of determining the zoning fee. However, in this context, a problem occurred to precisely describe specific actions that entail the obligation of payment of the analysed public levy. The above issue became the subject of many decisions issued by administrative courts. For some time, the judicial decisions included two different views on the above-mentioned issue. The first opinion expressed, among other things, in the judgement of the Supreme Administrative Court of 17 July 2008, showed that the 'disposal of the property' referred to

55 Judgement of the Voivodeship Administrative Court in Warszawa of 10 March 2006, IV SA/Wa 2265/05, LEX No. 222281.

56 Rokicka-Maruszewska, K., op. cit., p. 161.

57 Bieniek, G. and Rudnicki, S., Nieruchomości. Problematyka prawna, Warszawa 2011, p. 939.

58 Judgement of the Supreme Administrative Court of 21 May 2007, II OSK 814/06, LEX No. 338319.

59 Judgement of the Voivodeship Administrative Court in Poznań of 15 May 2019, II SA/Po 102/19, LEX No. 2677719.

60 Act of 28 November 2003 amending the Act on real estate management and certain other acts, consolidated text: Dz.U. (Journal of Laws) of 2004, No. 141, item 1492. 
all methods of land disposal (both sale and donation). ${ }^{61}$ The aforesaid position was approved in the decision of the Voivodeship Administrative Court in Gdańsk of 14 January 2009, in which the Court explicitly stated that the transfer of ownership title to the land by way of donation constitutes disposal in compliance with Article $36 \mathrm{sec} .4$ of the Act. Since the analysed legal act lacks the definition of the 'disposal of the property', the term should be interpreted in line with the definition included in the Act on real estate management, which covers all legal actions within the scope of the aforesaid term, as a result of which the ownership title is transferred. ${ }^{62}$ On the other hand, in its judgement of 25 March 2009, the Voivodeship Administrative Court in Wrocław concluded that the fee charged to the owner in the case of the land disposal did not depend on whether the owner derived any profits due to such disposal. What is important is the disposal of the land, whose value increased as a result of the changed purpose of the land in the local spatial development plan. In the opinion of the Voivodeship Administrative Court in Wrocław, the fact that the contract for donation to a relative or stranger was excluded from the scope of Article $36 \mathrm{sec} .4$ lacks normative justification. ${ }^{63}$ What is more, a different view is included in the decisions of administrative courts, e.g. the judgement of the Voivodeship Administrative Court in Szczecin of 8 May 2008, in which the Court informed that if, due to the adoption or change of the plan, the value of the land increased, only the disposal against payment would increase the assets of the seller and generate additional profits. ${ }^{64}$ Nonetheless, if the ownership title is transferred under the contract without payment, the change of the plan will not have any impact on the assets and additional profits. In light of the above, there are no grounds for charging the land owner with the fee. The above-mentioned position was accepted, for example, in the judgement of the Voivodeship Administrative Court in Lublin of 27 November $2008^{65}$ and the judgement of the Voivodeship Administrative Court in Olsztyn of 3 November $2009^{66}$, in which the Courts stated that if, due to the adoption or change of the plan, the value of the land increased, then the fee

61 Judgement of the Supreme Administrative Court of 17 July 2008, IIOSK 877/07, LEX No. 493241.

62 Judgement of the Voivodeship Administrative Court in Gdańsk of 14 November 2009, II SA/Gd 799/08, LEX No. 481500.

63 Judgement of the Voivodeship Administrative Court in Wrocław of 25 March 2009, II SA/Wr 478/08, LEX No. 495398.

64 Judgement of the Voivodeship Administrative Court in Szczecin of 8 May 2008, II SA/Sz 976/07, LEX No. 519055.

65 Judgement of the Voivodeship Administrative Court in Lublin of 27 November 2008, II SA/Lu 575/08, LEX No. 521902.

66 Judgement of the Voivodeship Administrative Court in Olsztyn of 3 November 2009, II SA/Ol 790/09, LexPolonica No. 2125740. 
could be determined only in the case of chargeable disposal of the land that would allow the disposing entity to increase their assets and generate profits. Finally, the second position prevailed, which was reflected in the resolution passed by seven judges of the Supreme Administrative Court on 10 December 2009. In compliance with the aforesaid resolution, the fee could not be established in the event when the land was donated to a relative. The Supreme Administrative Court emphasised that the term 'sale' used in Article $37 \mathrm{sec} .1$ did not constitute the omission on the part of the legislator, as certain amendments to the Act did not change this regulation. Since the current wording of the provisions impose the obligation to set the fee amount on the day of its sale, it is an explicit indication by the legislator that the fee is absolutely connected with the land disposal characterised by functional equality (payment). However, if the transaction is equivalent, the payment obligation does not arise. ${ }^{67}$ The zoning fee amount is determined on the day of the sale of the land. The fee is established on the basis of the decision issued by a competent authority, i.e. the commune head, mayor, or president of the city, immediately upon receipt of the excerpt from the notary deed confirming the execution of the agreement, whose subject matter included the disposal of the land. ${ }^{68}$ The aforementioned decision, or rather its issuance, is obligatory.

The regulation in the analysed Act is worthy of attention. The owner or perpetual usufructary, whose land's value increased due to the adoption or change of the plan before the land was disposed, is entitled to request that the commune's executive body determine the zoning fee amount by way of a decision. The purpose of the above is to allow the seller to learn about the amount of public and law charges, which will result from the disposal of a specific immovable property. Additionally, it is a kind of guarantee, as the fee amount should not be higher than the planned amount. ${ }^{69}$ However, if the above situation occurs, the activities of the executive body could be treated as flagrant violation of the trust principle. Pursuant to Article $37 \mathrm{sec} .7$ of the Act, the owner or perpetual usufructary of the property, whose value increased due to the adoption or change of the local spatial plan may - -prior to its disposal- - request the commune head, mayor, or president of the city to determine the fee by way of a decision, according to Article $36 \mathrm{sec} .4$ of the Act. Unlike Article $36 \mathrm{sec} .4$ of the Act, the subject of the decision issued pursuant to Article $37 \mathrm{sec} .7$ of the Act is not the 'collection' of a one-off payment, but

67 Resolution passed by seven judges of the Supreme Administrative Court of 10 December 2009, II OPS 3/09, "Orzecznictwo Naczelnego Sądu Administracyjnego i Wojewódzkich Sądów Administracyjnych" 2010, No. 2, item 22.

Bieniek, G. and Rudnicki, S., Nieruchomości. Problematyka prawna, Warszawa 2004, p. 11.

69

Rokicka-Maruszewska, K., op. cit., p. 239. 
the 'determination of its amount'. Such an interpretation of the above-mentioned provision corresponds to the very purpose of the discussed legal measure. The provision allows the owner or perpetual usufructary to determine whether the zoning fee will be charged thereto in the case of the disposal of the property and, if so, in what amount. The right vested in the owner or perpetual usufructary of the property under Article $37 \mathrm{sec} .7$ of the Act allows learning about the zoning fee amount already before the disposal of the property for the purpose of including such fee in the sales price or renouncing the intention of sale. However, the decision issued pursuant to Article $37 \mathrm{sec} .7$ of the Act does not impose the obligation to pay the zoning fee. It does not constitute the enforceable title subject to mandatory execution as part of the administrative enforcement proceedings. The decision issued pursuant to Article $37 \mathrm{sec} .7$ of the Act, which only defined the 'amount' of the fee mentioned in Article $36 \mathrm{sec} .4$ of the aforesaid Act constitutes a kind of promise for the owner or perpetual usufructary. It should be remembered that to charge the zoning fee, the public administration body must - apart from acknowledging the increase of the property value - ascertain the disposal of the property and report the 'claim' no later than 5 years after the day on which the spatial development plan or amendment thereto became effective. The above should be effected in the decision issued on the basis of Article $36 \mathrm{sec} .4$ of the Act. Therefore, the purpose of the discussed instrument is to ensure the legal situation of the owner or perpetual usufructary of the property so that when they dispose of the property, the competent body reports the 'claim' within 5 years from the day on which the spatial development plan or amendment thereto became effective, and the fee in the form of the interest rate on the value previously set in the decision according to Article $37 \mathrm{sec}$. 7 of the Act will be collected. Therefore, the operative part of the decision delivered pursuant to Article $37 \mathrm{sec} .7$ of the Act should be only limited to the 'determination of the fee amount' in connection with the intention to dispose of the property. On the other hand, to impose the obligation of payment of the zoning fee ('fee collection'), it is necessary to issue another decision based on Article $36 \mathrm{sec} .4$ of the Act. It is not possible to establish the zoning fee once again ex officio, pursuant to Article $36 \mathrm{sec} .4$ of the Act, if it was already determined upon a request on the basis of Article $37 \mathrm{sec} .7$ of the said Act. ${ }^{70}$ The purpose of this solution is to enable the owner or perpetual usufructary of the property to obtain the information on the amount of the zoning fee before the disposal of the property. The solution allows the entity, which is the addressee of such obligation, to include the financial charges in the

70 Judgement of the Supreme Administrative Court of 9 March 2010, II OSK 483/2009, LexPolonica No. 2265514. 
economic balance of the potential transaction. If the solution is used by the entity - -the owner or perpetual usufructary of the property- - it allows to avoid surprise caused by the zoning fee set ex officio on the basis of the decision issued pursuant to Article $36 \mathrm{sec} .4$ of the Act. After conducting the proceedings upon the request of the owner or perpetual usufructary of the property, the competent public administration body issues the decision to establish the zoning fee amount. The administrative pronouncement does not establish the amount of the zoning fee. Its aim is to determine the zoning fee amount, which the addressee of the act will be obliged to pay once the decision becomes final. And the point here is not 'preliminary' determination of such fee. Such an approach would constitute grounds for formulating the assumption that the fee will be then modified or approved by way of a resolution in compliance with Article $36 \mathrm{sec} .4$ of the Act. ${ }^{71}$ The administrative pronouncement understood in such a manner, delivered pursuant to Article $37 \mathrm{sec} .7$ of the Act, has constitutive nature. Nevertheless, the established obligation to pay the zoning fee by the owner to the commune is connected with a condition precedent, which consists in the disposal of a given property in the future. If this obligation is not fulfilled, the obligation to pay the established amount does not arise. It should be assumed that the effects of this decision are not limited by any deadline. Therefore, it should be presumed that the obligation may arise as long as the decision remains part of the legal transactions. As a result of this assumption, it is deemed that the final decision issued pursuant to Article $37 \mathrm{sec} .7$ of the Act creates the res iudicata status and hence makes it impossible to deliver the decision based on Article $36 \mathrm{sec} .4$ of the aforesaid Act under pain of invalidity of the latter in compliance with Article $156 \$ 1$ point 3 of the Code of Administrative Procedure. This view is also supported by the judicial decisions of the Supreme Administrative Court. ${ }^{72}$ By virtue of Article 37 sec. 3 and sec. 4 of the Act, the executive body is additionally limited in the possibility of issuing the decision on the zoning fee. ${ }^{73}$ Namely, the body is obliged to initiate the proceeding ex officio within 5 years from the effective date of the local spatial development plan. The view is supported by the judicial decisions of administrative courts. In its judgement of 4 February 2011, the Supreme Administrative Court showed that the appropriate application of Article $37 \mathrm{sec} .3$ of the Act to payments mentioned in Article $36 \mathrm{sec} .4$ of the aforesaid Act

71 Decision of the local government appeal council in Wrocław of 24 October 2013, SKO 4125/47/13, "Orzecznictwo w Sprawach Samorządowych" 2014, No. 2, pp. 49-53.

72 Judgement of the Supreme Administrative Court of 9 March 2010, II OSK 483/2009, LexPolonica no. 2265514.

73 Niewiadomski, Z., Ustawa o planowaniu i zagospodarowaniu przestrzennym. Komentarz, 2nd edition, Warszawa 2005, p. 292. 
should be understood in such a manner that the commune head, mayor, or president of the city should initiate, within 5 years from the day on which the local plan or amendment thereof became effective, the administrative proceedings (ex officio) concerning a one-off fee due to the increase of the property value. The time limit of 5 years mentioned in Article $37 \mathrm{sec} .3$ of the Act should be understood as the claims' period of prescription according to civil law and the maximum period during which the administrative proceedings may be initiated to determine the fee resulting from the increase of the property value, and not as the deadline limiting the issuance of the decision in the case. ${ }^{74}$ The deadline stipulated in this provision should be included in the category of final dates. Its expiration excludes the possibility to seek to collect the zoning fee. ${ }^{75}$ In summary, the fee due to the increase of the property value may be established if, within the 5-year period, the authority submits a claim in this regard. The submitted claim may be in the form of the notice of initiation of the administrative proceedings concerning the determination of the zoning fee. ${ }^{76}$ In light of the above, it may be deduced that the establishment of the zoning fee may hinder the disposal of the property after 5 years from the effective date of the new plan. The fee amount is determined by the commune authorities. The maximum statutory threshold is $30 \%$. However, the limit is often much lower, for example, $0.01 \%$. The above-mentioned time limits have caused almost all entities to refrain from the disposal of properties. It is only after 5 years that they start selling their properties and derive profits due to the increased value. Public entities, such as communes, have not received any payments, as the sellers prolonged the sales process.

What is worth considering is the amendment to the Act in the form of the discussed fee established at a fixed level of $30 \%$ of the increased value and the elimination of time limits. Or, alternatively, the introduction of the minimum amount of the fee below which the prices may not go. The above could change the current practice, in accordance with which the owners to a large extent do not participate in the costs of spatial planning.

Sometimes certain communes establish $0 \%$ fee rates. As a result of particular court judgements, the communes abandoned this bad practice. There are also some demands to eliminate the above instrument from the Act. However, it is impossible to accept such demands, as the fee constitutes an important element of the

74 Judgement of the Supreme Administrative Court of 4 February 2011, II OSK 207/10, LEX No. 753419.

75 Rokicka-Maruszewska, K., op. cit., p. 198.

76 Judgement of the Supreme Administrative Court of 6 December 2012, II OSK 1394/11, LEX No. 1367246. 
commune's income. Therefore, it would be more reasonable to introduce other changes, such as, for example, the fixed amount of the zoning fee, without the statute of limitations.

The owners who dispose of their land have perfectly learnt to circumvent the regulations to avoid payment of the zoning fee. It is enough that within 5 years from the date of adoption of the plan, they conclude a preliminary contract for the sale of land. ${ }^{77}$ The actual contract is signed when the aforementioned period expires. ${ }^{78}$

\section{Conclusion}

The zoning fee is a special reflection of the commune's share in profits obtained by the sellers of lands, whose value increased due to the new purpose defined in the local spatial development plan. The conditions allowing public entities to charge the sellers with the zoning fee have caused interpretation problems. The problems concerned the determination of such fee in the case of the land disposal based on the contract of donation or determination of the amount of interest rates. The donation is of a public-law nature - it is not a tax. The zoning fee does not follow from the Act and does not have an unpaid character. Therefore, it is not a tax in compliance with the definition in Article 6 of the Tax Ordinance Act. Despite the fact that the zoning fee constitutes a public-law liability (public levy under administrative law), it may not be treated as a kind of tax, as it does not result from the Tax Ordinance Act (Article 6) and, unlike tax, it has equivalent character in the form the commune's share in profits derived by the property owners in connection with the adoption of the local spatial plan (judgement of the Supreme Administrative Court of 18 May 2010, II OSK 1809/09). The above shows that these are not the provisions of the Tax Ordinance Act that apply to the proceedings for establishing the zoning fee, but the provisions of the Code of Administrative Procedure. The zoning fee, being a public-law liability, has legal effect within the framework of the administrative relationship. The administrative decision is the source of the obligation to pay such fee. ${ }^{79}$

The zoning fee, which is not a tax, obviously constitutes a non-taxable budgetary public-law receivable of the local government unit, within the meaning of Article

77 Rudnicki, S., Własność nieruchomości, Warszawa 2007, p. 167.

78 Żylińska, J., Właściciele gruntów nie uciekna przed renta planistyczną, https://www.serwisy.gazetaprawna.pl/nieruchomosci/artykuly/1417798,renta-planistyczna-pozmianie-planu-miejscowegoprzepisy.html (accessed 06.03.2020).

79 Judgement of the Voivodeship Administrative Court in Poznań of 14 March 2013, II SA/Po 60/13. 
60 of the Act of 27 August 2009 on Public Finance, since the zoning fee is the budgetary income of the local government unit. ${ }^{80}$ Such an understanding of the purpose of the zoning fee is in line with the purposes for which it was created: first of all, to 'share' profits derived by the property owner; second of all, to prevent 'speculative' trading in immovable property directly after the adoption or change of the plan. The purpose of charging the zoning fee is to compensate the local government units of the lowest level for the expenses they incurred due to the adoption of the local spatial development plans and encourage them to implement the plans. The payment of the zoning fee is obligatory.

The amount of the public levy is determined by the commune's decision-making bodies $--30 \%$ is the upper statutory limit. However, in practice, this threshold is sometimes lower. The aforementioned time limits have caused the substantial part of entities potentially obliged to pay the zoning fee to refrain from the disposal of their properties. They start selling the properties and derive profits due to the increased value only 5 years later. Public entities such as communes do not receive any payments, hence they do not generate the expected profits due to the prolonged sales process.

What is worth considering is the amendment to the Act in the form of the subject levy established at a fixed level of $30 \%$ of the increased value and the elimination of time limits.

Or, alternatively, the introduction of the minimum amount of the fee below which the price may not go. The above could change the current practice, in accordance with which a substantial part of the owners do not participate in the costs of spatial planning or participate only to a small extent.

The local plans put the obligation on the communes to implement the regulations included in such plans. It involves substantial costs, e.g. implementation of the technical infrastructure, purchase of lands for public purposes or satisfaction of claims of the owners due to the decrease of the property value. ${ }^{81}$ The provisions in the plans may also have impact on the increase of the commune's income thanks to, among other things, the proceeds from the property brokerage services, property tax, or adjacent fees. Furthermore, the commune's income may also come derived from the zoning fees. ${ }^{82}$ The above-described issues should be specifically

80 Act of 27 August 2009 on public finance, consolidated text: Dz.U. (Journal of Laws) of 2019, item 869.

81 Hełdak, M., Teoretyczne i praktyczne aspekty ustalania wysokości 'opłaty planistycznej, "Studia i Materiały Towarzystwa Naukowego Nieruchomości” 2008, No. 16(1), p. 115.

82 Sulczewska, K., Opłata planistyczna oraz opłata adiacencka - uzasadnienie aksjologiczne i analiza porównawcza, "Studia Prawno-Ekonomiczne" 2014, Vol. XCII, p. 129; Padrak, R., Ustalanie opłaty 
defined in the so-called forecast of the financial impact of a given plan (Article 17 point 5 of the Planning and Development Act). The communes, while bearing the costs related to the adoption of the local plans, are interested in the share of profits generated therefrom by the land owners. It is made possible thanks to, among other things, the zoning fee, which is a tool for shaping market behaviours and type of participation of the land owners in the costs of the adoption of the local spatial development plans. ${ }^{83}$

With the above in mind, it should be stated that it is justified to keep the aforesaid measure in the Polish legal framework, as it actually has a positive impact on communes' budgets, and the propounded changes only enhance this effect.

\section{References}

Bieniek, G. and Rudnicki, S., Nieruchomości. Problematyka prawna, Warszawa 2004.

Bieniek, G. and Rudnicki, S., Nieruchomości. Problematyka prawna, Warszawa 2011.

Bieniek, G. et al., Ustawa o gospodarce nieruchomościami. Komentarz, Warszawa 2005.

Bieniek, G., et al., Ustawa o gospodarce nieruchomościami. Komentarz; Warszawa 2012.

Borodo, A., Finanse publiczne RP. Zagadnienia prawne, Bydgoszcz 2000.

Budner, W., Gospodarka przestrzenna miast i aglomeracji, 1st edition. Poznań 2019.

Brzezicki, T. et al., Opłaty i wybrane roszczenia dotyczace nieruchomości, Warszawa 2018.

Gdesz, M. and Trembecka, A., Regulowanie stanu prawnego nieruchomości pod drogi, Katowice 2011.

Hełdak, M., Teoretyczne i praktyczne aspekty ustalania wysokości 'opłaty planistycznej', "Studia i Materiały Towarzystwa Naukowego Nieruchomości" 2008, No. 16(1).

Jaworski, J. et al., Ustawa o gospodarce nieruchomościami. Komentarz, 5th edition, Warszawa 2017.

Leoński, Z. et al., Prawo zagospodarowania przestrzeni, Warszawa 2019.

Niewiadomski, Z., Planowanie i zagospodarowanie przestrzenne. Komentarz, Warszawa 2009.

Niewiadomski, Z., Planowanie i zagospodarowanie przestrzenne. Komentarz, Warszawa 2015.

Niewiadomski, Z., Ustawa o planowaniu i zagospodarowaniu przestrzennym. Komentarz, Warszawa 2005.

planistycznej - procedura, przesłanki oraz propozycje zmian w obowiązujacym prawie, "Kontrola Państwowa" 2015, No. 2(60), p. 116.

83 Zaremba, A., Uwarunkowania rozwoju rynku nieruchomości, jako istotnego czynnika rozwoju lokalnego, "Journal of Agribusiness and Rural Development" 2011, No. 1(19), p. 115. 
Nowak, M.J. and Tokarzewska-Żarna, Z., Gospodarka nieruchomościami. Kluczowe problemy prawne, Warszawa 2017.

Nowak, M.J., Planowanie i zagospodarowanie przestrzenne. Komentarz do ustawy i przepisów powiązanych, Warszawa 2019.

Padrak, R., Ustalanie opłaty planistycznej - procedura, przesłanki oraz propozycje zmian w obowiązującym prawie, "Kontrola Państwowa” 2015, No. 2(60), p. 116.

Plucińska-Filipowicz, A. and Wierzbowski, M., Ustawa o planowaniu i zagospodarowaniu przestrzennym. Komentarz, Warszawa 2018.

Rokicka-Maruszewska, K., Administracyjnoprawne aspekty opłaty planistycznej, Warszawa 2019.

Rudnicki, S., Własność nieruchomości, Warszawa 2007.

Mielcarek, P. et al., Akta administracyjne dla aplikantów, Warszawa 2016.

Strzelczyk, R., Podatki i opłaty dotyczące nieruchomości, Warszawa 2016.

Sulczewska, K., Opłata planistyczna oraz opłata adiacencka - uzasadnienie aksjologiczne i analiza porównawcza, "Studia Prawno-Ekonomiczne" 2014, Vol. XCII.

Zaremba, A., Uwarunkowania rozwoju rynku nieruchomości, jako istotnego czynnika rozwoju lokalnego, "Journal of Agribusiness and Rural Development" 2011, No. 1(19).

Źróbek, S. et al., Gospodarka nieruchomościami. Komentarz do wybranych procedur, Katowice 2011.

Żylińska, J., Właściciele gruntów nie uciekna przed rentą planistyczną, https://serwisy. gazetaprawna.pl/nieruchomosci/artykuly/1417798,renta-planistyczna-po-zmianieplanu-miejscowego-rzepisy.html.

\section{CITATION}

Stawecki, M., Zoning fee as a public levy, “Acta Iuris Stetinensis” 2020, No. 4 (Vol. 32), 93-115, DOI: 10.18276/ais.2020.32-07. 